\title{
ЭСТЕТИКА
}

\author{
Е.Л. Скворцова, А.Л. Луцкий
}

\section{ЭКЗИСТЕНЦИАЛИЗМ В ЯПОНИИ И ЕГО ВЛИЯНИЕ НА ТВОРЧЕСТВО ПИСАТЕЛЯ СИИНА РИНДЗО}

\begin{abstract}
Аннотация. В статье рассматриваются особенности восприятия философии экзистенциализма в Японии и анализируется влияние экзистенциалистских идей на творчество писателя Сиина Риндзо. Констатируется, что традиционное японское восприятие человека как причастного миру во многом противоположно западному эгоцентрическому экзистенциальному мировосприятию индивидуума как замкнутого на своём "Я". Однако существует определённая близость экзистенциалистских и буддийских мировоззренческих установок, что способствовало распространению экзистенциализма в Японии. По мере развития капиталистических отношений в этой стране в японском общественном сознании получили распространение индивидуалистические настроения. Для японских экзистенциалистов главной проблемой стало определение и утверждение собственного "я". В статье использован эмпирико-герменевтический метод, т.е. метод корректного описания и толкования конкретных источников, а также диалектический метод в сочетании с принципом комплементарности. В статье впервые в истории отечественного литературоведения рассмотрены работы японского прозаика Сиина Риндзо в свете распространения идей экзистенциализма в Японии; впервые сделан перевод с японского языка текстов Сиина Риндзо и литературно-критических работ, посвящённых его творчеству; впервые предложен культурологический анализ текстов Сиина Риндзо; впервые для подобного анализа привлечены оригинальные японские культурологические и философские источники. Авторами статьи делаются выводы о том, что экзистенциалистские мотивы произведений Сиина Риндзо близки экзистенциализму Достоевского, а в образах героев этого японского писателя нашли отражение его этические искания, созвучные идеям представителя католического экзистенциализма Габриэля Марселя.
\end{abstract}

Ключевые слова: Сиина Риндзо, Япония, группа "сэнгоха", буддийско-конфуцианская традиция, буддизм, Достоевский, индивидуализм, нигилизм, философия экзистенциализма, личность, смерть.

Abstract. The subject of the research is the peculiarities of introduction and perception of existential philosophy in Japan, in particular, the influence of the existential philosophic thought on Siina Rinzo' works. The authors of the article state that within the Japanese culture a traditional attitude to a human being as a creature deeply involved in the natural and social world had been (at least up to the middle of the 20th c.) opposed to the Western one, taking a human being as an individual withdrawn into himself. Also, a considerable proximity can be found between existential and Buddhist mentalities which had favored the spread of existential philosophy in Japan. However, spreading of Capitalism in Japan led to strengthening of individualistic tendencies in Japanese society. Consequently, the main problem for existentiallyoriented Japanese writers became "maintaining and determination of their own Self" (Jiga). The method of research: The empirico-hermeneutic methodology was applied: i. e. the method of correct description and interpretation of original sources; dialectical methodology supplemented with the principle of complementarity. Scientific novelty and conclusions: for the first time in Russian history of literature studies, the original texts both by Siina Rinzo (in the light of existential thought in Japan) and Japanese literature critics, texts by dedicated to Siina had been translated and analyzed; the authors also conclude that Siina's existential motives are much closer to those of Dostoevsky than to the Western representatives of existentially-oriented literature. The characters in Siina's works show obvious signs of their creator's ethical striving which leads Siina to the ideals consonant to be ones of a Catholic representative of existentialism Gabriel Marcel.

Key words: nihilism, individualism, Buddhism, Dostoevsky, Buddhist-Confucian tradition, the "Sengoha group", Japan, Siina Rinzo, existential philosophy, person.

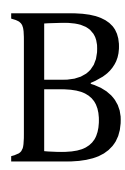

художественной литературе Японии, подобно тому, как это происходило на Западе, экзистенциалистские тенденции обозначились и получили развитие в период по- сле Второй мировой войны [8]. Но ещё задолго до того, как в послевоенной Японии воцарился ценностный хаос, а жителей охватило чувство беспочвенности жизни и бессмысленности человеческого 
существования, по Европе прокатились несколько волн нигилистических настроений [30], оформившихся в итоге в философию экзистенциализма. Подобные настроения нашли отражение в творчестве литераторов группы Сэнго-ха (Послевоенная группа): Хания Ютака, Нома Хироси, Сиина Риндзо, Мисима Юкио, Оока Сёхэй, Накамура Синъитиро, Исихара Синтаро и др. Своим творческим методом они объявили принцип киндайсюги, который соответствовал западному понятию «модернизм». Произведения авторов сэнго-ха опирались на горький военный опыт, когда «пограничные ситуации» - переживание личностью экстремальных состояний - были обыденным явлением. По наблюдению К. Рёхо, мировоззренческой основой сэнго-ха стал экзистенциализм [15, с. 87].

Прежде чем перейти к анализу экзистенциалистских тенденций в творчестве Сиина Риндзо, скажем несколько слов о распространении экзистенциалистских идей в Японии. На протяжении всей истории страны важное, а часто и главенствующее место в общественном сознании принадлежало религиозным и этическим учениям и прежде всего буддизма. В Японии получили распространение две тенденции буддийской мысли, указывавшие две возможности самораскрытия сущности человека. Первая предполагала самораскрытие посредством вовлечённости индивида в социальную жизнь и подчинения всех его интересов интересам общества. Вторая, напротив, призывала к бегству от социальных уз как неистинных, и культивировала идеал отшельничества. Проникновение в Японию конфуцианства относят к IV в. Coседствуя с буддизмом и постепенно набирая силу в течение XII-XVI вв., конфуцианство к XVII в. заняло там место господствующей идеологии. Буддийскоконфуцианская традиция продолжала монопольно господствовать в духовной жизни общества до второй половины XIX в.

Новые тенденции в идеологии наметились после произошедшей в 1868 г. так называемой реставрации Мэйдзи, когда Япония, вовлекаемая в орбиту мирового сообщества и всё более интенсивно развивавшая производительные силы, пошла по капиталистическому пути. Под влиянием утверждавшегося способа производства происходило разрушение не только экономических, но и традиционных социальных связей, что повлекло за собой перемены в японской духовной сфере. На эти перемены влияло также усвоение ценностей западной цивилизации, причём чужеземная духовная культура воспринималась японцами сначала как некий монолит, единое целое. Философские идеи, которые в Европе вызревали длительное время, постепенно становились популярными и постепенно исчезали, проникли в общественное сознание Японии в необычайно короткий срок. Естественно, что японским учёным, чьи мировоззренческие установки традиционно развивались в русле религиозноэтических и отчасти эстетических учений, нелегко было разобраться в богатейшем философском наследии Запада.

.Воодушевлённые своими первыми успехами в экономике, которые приписывались распространению духа рационализма, японцы выдвинули лозунг «Рационализм!». Разумеется, они не могли не обратиться и к вершинам мировой рационалистической мысли - сочинениям немецких философов-классиков [16]. Тон задавал гегелевский идеал рационального, упорядоченного человека, выступающего как часть целого (государства) и подчинённого интересам и задачам этого целого. Однако наиболее прозорливые мыслители Японии предвещали неизбежное разочарование в образцах западной духовной традиции, предупреждали об опасности утраты национальной самобытности. Один из них, Окакура Какудзо (1862-1913), писал: «Задача Азии - в защите и восстановлении азиатских путей. Но чтобы сделать это, она должна сама осознать и развить эти пути. Ведь тени прошлого - это обещание будущего» [31, р. 140].

Со временем рационалистический пыл японцев несколько охладился. Вслед за европейцами они убедились в весьма ограниченных возможностях научно-технического прогресса при решении социальных проблем. Ещё более ограниченными были возможности рационалистической философии, ориентированной на абстрактное теоретизирование и занятой созданием идеализированных схем мирового развития. Взоры устремились к нерационалистическим направлениям философской мысли Запада. И тут произошёл любопытный феномен, заслуживающий названия «восприятие через узнавание». Его суть состояла в том, что японцы отдали свои симпатии тем направлениям европейской общественной мысли (в частности, экзистенциализму), в которых содержались идеи, созвучные идеям буддийско-конфуцианской традиции. По наблюдению Т.П. Григорьевой, «внимание японцев привлекли именно те поэты и философы, которые были близки им по духу или в которых они узнавали себя, хотя и не отдавали себе в этом отчёта, причём они принимали за откровение давно им знакомое» [2, с. 34]. Напомним, что предтечи заинтересовавших японцев иррационалистических и близких к направлениям западной философии, такие как А.Шопенгауэр (1788-1860) и Ф. Ницше (1844-1900), сами испытали сильное воздействие восточной мыслительной традиции. Как писал А. Швейцер, «завоевания оптимистической китай- 
ской и пессимистической индийской философии особенно явственно обнаруживают себя в Европе в учении Ницше и Шопенгауэра» [27, с. 251]. Взгляды этих двух мыслителей получили дальнейшее развитие в работах представителей «философии жизни» и феноменологии, оказавших в свою очередь влияние на творчество М. Хайдеггера (1889-1976), одного из столпов философии экзистенциализма.

Экзистенциалистские настроения - это настроения взбунтовавшегося против своей униженности индивидуума, возомнившего себя основой и смыслом бытия и тяготящегося своим существованием в мире всеобщей раздробленности, где каждый сосредоточен на самом себе. Экзистенциалистский индивидуализм неслучайно родился в среде европейских интеллигентов - носителей духовной культуры Запада, индивидуалистический характер которой начал складываться ещё в античности и утвердился в эпоху Ренессанса. Японии же свойственны иные культурные традиции, имеющие ярко выраженную неличностную, неиндивидуалистическую окраску. Тем не менее, индивидуалистическая философия экзистенциализма пустила корни и на Японских островах.

В Японии экзистенциализм, как было указано выше, начал утверждать свои позиции в 1930-40-е гг. и стал особенно популярен в послевоенный период [20, с. 132-139]. Появление и распространение здесь этой философии было обусловлено, по нашему мнению, двумя причинами. Во-первых, существовала определённая близость экзистенциалистских и неотделимых от традиционной японской культуры буддийских мировоззренческих установок. Та самая близость, благодаря которой стал возможен уже описанный выше феномен «восприятия через узнавание». Например, творческий метод экзистенциалиста Хайдеггера весьма созвучен японской мыслительной традиции и состоит в том, чтобы понять явное через неявное, то, что сказано, через то, что не может быть сказано, понять слово через молчание, сущее - через не-сущее, бытие - через ничто [23, с. 202]. Так, в беседе с одним из представителей самобытной неевропейской культуры - японцем - Хайдеггер помогает своему собеседнику выявить смысл некоторых японских слов, в том числе и слова ку, которое по значению близко понятию ничто. Вот что говорит собеседник Хайдеггера по поводу этого понятия: «Мы и сегодня ещё удивляемся, как европейцы смогли пасть до того, чтобы ничто толковать нигилистически. У нас пустое есть высшее наименование того, что вы назвали бы словом бытие» [26, с. 281]. Чувствуя близость своих мировоззренческих установок буддизму, Хайдеггер в последние годы жизни уделял много внимания изучению трудов буддийских идеологов. В свою очередь крупнейшие философы буддийской ориентации XX в. Вацудзи Тэцуро и Танабэ Хадзимэ считали Хайдеггера своим учителем [1; 22]. В Японии даже были напечатаны работы, утверждавшие, что «благодаря экзистенциализму Хайдеггер гораздо ближе японцам, нежели европейцам» [10, с. 25].

Второй причиной распространения экзистенциалистской философии в японском обществе является, на наш взгляд, то, что буддийская Япония стала капиталистической и в её социальной жизни начали происходить процессы, подобные процессам, вызвавшим экзистенциалистские течения на Западе. Постепенно и в общественном сознании, и в самой японской действительности образовалась реальная основа для дальнейшего взаимодействия буддизма и экзистенциализма. «Проблема относительной совместимости экзистенциализма с традиционной японской мыслью выступает фактически как проблема взаимодействия этого философского течения с традиционной религиозной и философской буддийско-конфуцианской духовной культурой» $[6$, с. 26], - указывает исследователь японского экзистенциализма Ю.Б. Козловский. Решению данной проблемы посвящают свои усилия многие современные учёные Японии. С одной стороны, их представляют философы-экзистенциалисты, пытающиеся с помощью буддийской догматики преодолеть кризис «философии существования»; с другой - теоретики буддизма, стремящиеся модернизировать буддийскую идеологию путём привлечения экзистенциалистского мировоззренческого материала $[11 ; 12 ; 21]$.

На сходство буддизма и экзистенциализма указывают такие японские философы как Ниситани Кэйдзи, Юаса Ясуо, Имамити Томонобу, Умэхара Такэси, Идзуцу Тосихико и Идзуцу Тоё. Последние, «чтобы выявить философские структуры, лежащие в основе японской культуры» [29, р. IX], пытаются осуществить «синтез» экзистенциалистских идей с философскими установками буддизма и понятиями традиционной японской эстетики. Если сравнить буддийскую и экзистенциалистскую мировоззренческие системы, то обнаружится, что у них действительно есть определённое сходство. Во-первых, обе они проникнуты духом антиинтеллектуализма и антипрагматизма. Экзистенциализм появился вследствие реакции на схематизм и всеобщую запрограммированность жизни в капиталистическом обществе. Такая жизнь рассматривается экзистенциалистами как результат рассудочного отношения к миру и человеку. Пагубность подобного отношения, утверждают они, заключается в прагматическом потреблении и мира, и человека, превратившихся в объект эксплуатации. В свою очередь и буддийские установки, направленные на вовлечён- 
ность индивида в природно-социальный или космически-природный универсум, также способствуют утверждению живого, заинтересованного, а не рассудочно-холодного отношения к событиям, происходящим вокруг, и препятствуют возникновению потребительского отношения к миру и человеку.

Во-вторых, и буддизм, и экзистенциализм - это психологизированные учения, объектом внимания которых является индивидуум. «Метафизические построения буддизма основаны на данных психологического анализа... С гносеологической точки зрения особенность буддийского стиля мышления, по мнению 0.0. Розенберга и Ф.И. Щербатского, состоит в том, что оно направлено на непосредственно переживаемое бытие» $[24$, с. 6]. Экзистенциальное мышление направлено на тот же объект. Единственная подлинная реальность в экзистенциализме - бытие человеческой личности, исходный момент всякого знания - анализ этого конкретного бытия. (Правда, экзистенциализм рассматривает человека в субъективном аспекте, а не как демонстрацию космического бега жизни, подобно «философии жизни» А. Бергсона. Последняя в данном отношении ближе буддизму, чем экзистенциализм). Однако экзистенциализм не солипсизм, так как предполагает наличие объективного бытия. Человеческое “Я”, преображая инертность и хаотичность этого бытия, лишь придаёт ему действительную значимость. В равной степени неправомерно приписывать солипсизм буддийскому учению хотя бы потому, что в буддийском бытии отсутствует деление на субъект и объект. Как пишет японский философ Миякава Хидэки, «позиция восточной онтологии представляет структуру мышления, основанную на рациональном дуализме "субъект-объект" лишь в качестве субъективной абстракции» [9, c. 194]. Индивидуум является «объектом спасения» и в экзистенциализме, и в буддизме. Несмотря на обилие различных направлений буддизма, все они признают, в сущности, индивидуальный путь спасения. Экзистенциализм также ориентирован на индивидуума, чьи психологические характеристики приобретают в экзистенциалистском учении онтологический статус. Следует учесть, что индивидуализирующий подход в экзистенциализме следствие утраты человеком лично-значимых, подлинных связей с другими людьми, гиперболизация личностных переживаний индивида, вызванных сознанием либо ложности, либо вообще невозможности целостного мировоззрения. Индивидуалистичность же буддийского пути спасения вызвана необходимостью для самого индивида спасти себя от страдания, обусловленного его бытием в мире.

Несмотря на указанное сходство буддизма и экзистенциализма, в данных мировоззренческих системах есть весьма существенные различия. Так, если буддийский индивид не отделяет себя от мира, то экзистенциалист, наоборот, противопоставляет себя миру. Буддист верит в «изначальную природу», которая добра и светла; верит, что человек наделён эти подлинным началом, принципиально лишённым ориентации на эгоизм. В экзистенциализме проявления человеческой субъективности абсолютизируются, выступают как онтологические сущности, что свидетельствует о крайнем индивидуализме адептов этой философии. В буддизме существует Идеал - Будда. В экзистенциализме такой конкретный идеал отсутствует, есть лишь стремление индивида к аутентичности бытия. Буддизм указывает путь к достижению идеала, предлагает всем индивидам общий путь спасения от страдания, так сказать, «положительную программу». Экзистенциализм ограничивается критикой неаутентичности бытия массы людей и рекомендует каждому индивиду находить свой путь аутентичного бытия.

Можно, видимо, констатировать, что буддийское восприятие человека как причастного миру во многом противоположно индивидуалистическому экзистенциалистскому восприятию индивидуума как замкнутого на своём “Я”. Поэтому неличностное, неэгоистическое сознание японца-буддиста легко противопоставить эгоцентризму западного индивида. Для человека, стремящегося к достижению идеала буддизма, не существует проблемы своего “Я”, отчуждённого и обособленного от внешнего мира и других людей и противопоставленного им, как это исторически сложилось у человека западной цивилизации. Естественно, что проблема личной свободы не стояла перед традиционно мыслящим японцем, в отличие от индивида Запада. Традиционный японец никогда не стремился к самоутверждению, подобно своему западному собрату, и экзистенциальные проблемы последнего, являющиеся оборотной стороной этого самоутверждения, были ему до определённого времени незнакомы.

Позволительно было бы предположить, что экзистенциализм в Японии невозможен, так как у японцев исторически сформировался буддийский взгляд на мир, предполагающий «неотчуждённость» личности от природы и общества. Раз нет отчуждения, противопоставления, то, казалось бы, нет и оснований для драматизации бытия. Тем не менее это не совсем так. Условия для возникновения драматического переживания индивидом были и в Японии, поскольку там тоже существовало отчуждение человеческой сущности, только в другой форме и по другим причинам, чем на Западе. По мере утверждения капитализма на Японских островах их жители оказались в квазизападной ситуации. Чтобы функционировать в этих услови- 
ях, японец должен был вести себя подобно западному индивидууму. Ему было необходимо такое же самосознание, т.е. следовало обрести поначалу “ $Я$ " западного типа, то самое “Я” - интегратор социальных функций, то самое “неподлинное $Я$ ”, которое не удовлетворяло экзистенциализирующего европейца. Иными словами, «деиндивидуализированные» японцы были вынуждены «индивидуализироваться» на западный манер.

Кроме того, после знакомства с духовной культурой Запада с её сильным личностным началом творчески мыслящие японцы попали под её обаяние. Им тоже захотелось «свободы личности», «социальной независимости» и тому подобных ценностей западной цивилизации. Характерным примером духовных поисков японской интеллигенции может служить деятельность литературного объединения и одновременно гуманистического движения Сиракаба (Белая берёза), образованного на базе одноимённого журнала, который издавался группой студентов-аристократов токийской школы пэров Гакусюин. Центральным в творчестве писателей этого объединения, таких как Мусянокодзи Санэацу, Арисима Такэо и Сига Наоя было стремление обозначить своё авторское эго, своё “Я”, проявить свою индивидуальность, обозначить свою личность. «Так, пантеистическая картина мира Мусянокодзи, сенсуалистическое восприятие Сиги, христианский мистицизм Арисимы обусловили формирование, соответственно, наивного идеализма и утопического социализма, интуитивизма и экзистенциализма в мысли писателей» [4, с. 11]. Будучи по своим духовным истокам наследниками буддийской традиции, эти писатели ощутили свою ущербность в том смысле, что при всей гармоничности и непротиворечивости идеала буддийского мироустройства они - даже в случае следования этому идеалу - были лишены возможности иметь «своё лицо», чувствовать свою неповторимую индивидуальность. И если сутью «несчастного сознания» европейских экзистенциалистов было трагическое переживание отчуждённости от «других», то специфической чертой экзистенциалистов буддийского толка на первом этапе явилось переживание, связанное с отсутствием личностного начала, отсутствием своего “ $Я$ ”.

Экзистенциальные переживания японца несколько отличаются от переживаний экзистенциалиста Запада. Западный индивид склонен считать свою сущность существующей «сама по себе», считать своё (а не то, которое приписывает ему общество) “Я” центром мироздания. Японец традиционно привык ощущать себя причастным миру и не мыслит себя вне общества. Он веками выступал прежде всего как представитель определённой со- циальной группы. Отождествляя себя с группой, он видел в ней свою сущность. Психологически японец был ничем вне социума, поэтому у него выработалась привычка рассматривать и оценивать себя, исходя из отношения членов этого социума. Японский индивидуализм гораздо моложе западного. У человека западной цивилизации становление индивидуалистического сознания проходило на протяжении веков и потому незаметно, естественно. Так же естественно утрачивались и сословно-корпоративные связи, буржуазные революции лишь конституционно оформили их распад. У японцев же эти социальные связи разрушались в течение двух-трёх поколений, они относительно недавно оторвались от «пуповины общинности», обретя взамен бремя индивидуальной свободы. На основании такой свободы европейские теоретики экзистенциализма выстраивают «субъектную онтологию», т.е. опредмечивают, делают до предела реальными определения индивидуального сознания. У японских экзистенциалистов эти определения распадаются, поскольку японец, повторим, традиционно прочно связан с откликом «другого» и утверждение собственного “Я” является для него главной проблемой.

Посмотрим теперь, каким образом экзистенциалистские идеи нашли отражение в творчестве писателя Сиина Риндзо (1911-1973). «Общая история японской литературы» указывает на огромное значение, которое «придавали Сиина и его единомышленники опыту переломных моментов человеческой жизни и описывали их в обострённо-резкой манере. Их творчество основывалось на экзистенциальном опыте, начало описанию которого было положено Ф. Достоевским» [14, с. 291]. Причисление Достоевского к экзистенциалистам является достаточно широко распространённым мнением, в частности, в авторитетном научном издании подчёркивается, что «в рамках собственно философской традиции Достоевский - мыслитель экзистенциального склада» [25, с. 177]. В таком утверждении есть определённый резон, другое дело, что Достоевский, как и прочие гении, не поддаётся заключению в рамки какого-либо одного художественного или мировоззренческого течения. Но если сравнивать героев русского писателя и близких к ним по духу героев Сиина Риндзо с героями экзистенциалистской литературы, то между ними явственно обнаружится ряд существенных различий.

Герои Достоевского, как и герои Сиина, решают в первую очередь морально-этические задачи [13, c. 162]. Главное в творчестве этого писателя - этические идеи, в частности, идея вины и искупления. Классических же экзистенциальных героев (за исключением персонажей религиозного экзистенци- 
ализма) занимает проблема подлинности человеческого существования, и главным является не этический, а онтологический аспект.

Свободная воля героев Достоевского, противопоставленная другим людям, нормам, ценностям считается произволом и осуждается. По мнению русского писателя, нельзя человеку ставить себя, свою волю превыше всего (Бога, жизни и свободы “Другого”). В экзистенциализме, наоборот, воспевается свободная - в том числе и от моральных норм - воля индивидуума, являющаяся единственным гарантом его подлинности. Следовательно, преодоление этических норм выступает частью становления аутентичности личности.

У подлинного индивидуума Достоевского акт свободной воли направлен на ближнего, и целью этого подразумевается в конечном счёте общественное благо, т.е. благо этих самых ближних. В экзистенциализме акт свободной воли подлинного индивидуума тоже направлен на “другого” как на объект, при этом главной целью является обретение подлинного себя. (Другие - это ад, заявлял Ж.-П. Сартр.) К такому обретению персонажи Достоевского приходят только после подавления своей воли, после смирения. Свободная от моральных норм воля рассматривается как искушение - от дьявола. Экзистенциалист же противостоит всем и лишь благодаря своей свободной воле приходит к подлинному себе, поэтому свободная воля предстаёт божественным даром небес.

Центральным положением «философии пограничной ситуации» (если использовать термин Ясперса) является то, что только через факт безнадёжного сопротивления человек возвращает себе утраченную связь с Творцом, который его покинул, - и в акте противостояния, совершая свой подвиг в одиночку, человек становится Богоравным. Эта позиция - равенство с Богом в сопротивлении Божественному равнодушию - характерная черта религиозного экзистенциализма. Способность к протесту трансформируется в густое вещество сопротивляющегося доктрине созидания - в этот момент униженный, страдающий, но восставший экзистенциалист (чьё кредо: «я сопротивляюсь следовательно, я творю») обретает бесконечную свободу, равную свободе Божественной.

Но вернёмся к творчеству Сиина Риндзо, отметив при этом, что японский вариант экзистенциализма этого писателя ближе к экзистенциализму Достоевского, чем к его западному варианту. Своё первое сочинение, рассказ «Семья» (Иэ), он опубликовал в 1939 г. в журнале «Синсосаку» (Новое творчество). Позже Сиина вспоминал, что стремился соблюдать принцип натурализма (сидзэнсюги) при написании этого рассказа. В 1941 г. он приступил к работе над автобиографической повестью «Пирушка в полночь» (Синъя-но сюэн), закончив её лишь в 1947-ом. Повесть сразу же обратила на себя внимание отечественной критики [18, с. 52-54]. По наблюдению К. Рёхо, «влияние экзистенциалистских идей, в которых Сиина Риндзо нашёл прибежище, сказалось на первом его послевоенном произведении, “Пирушка в полночь", где японский писатель понимает действительность как символическое воплощение духовных ценностей, как отражение индивидуального сознания» [15, с. 102].

Жизнь послевоенной Японии была отмечена ценностным хаосом, отсутствием общих смыслов, свирепыми условиями существования, правила поведения в которых диктовались способностью любыми методами противостоять другим. Философ Янагида Кэндзюро, подобно другим японским интеллектуалам мучительно искавший для себя подходящую жизненную позицию при тотальной разобщённости, атомизации общества, где каждый выступал сам за себя, свидетельствовал: «В хаосе, наступившем после военного поражения, японский народ не знал, что он должен делать. Казалось, будто все люди становятся всё более и более эгоистичными и всем управляет только стремление к личной выгоде. Никогда не бывало, чтобы японцы до такой степени отвратительно обнаружили свою сущность, отбросив всякий стыд и приличие. Стало ясным, что добродетели прежних дней оказались просто притворством и ханжеством. Когда молодёжь узнала, что всё прошлое было основано на лжи, она потеряла всякую веру в истины человеческой жизни... Это было общество, где слабохарактерному человеку просто невозможно было жить» $[28$, с. $110-111]$.

Такими слабохарактерными личностями выступают герои следующих после «Пирушки» книг Сиина, напечатанных в 1948 г. - повести «Во власти несущегося потока» (Омоки нагарэ-но нака-ни), романа «Вечный пролог» (Эйэн нару дзёсё) и повести «Записки Фукао Масадзи» (Фукао Масадзи-но сюки). В данных произведениях, по оценке Словаря современной японской литературы, Сиина Риндзо «воспринимает послевоенную эпоху как времена мрака и бессмысленности. Анализируя условия существования современного человека, он пытается постичь сущность нигилизма в духе Достоевского и Кьёркегора и выступает типичным представителем послевоенного поколения писателей, отдавших дань моде на экзистенциализм» [3, с. 342].

Страх перед тотальной и никого не щадящей смертью, осознание трагической пропасти между интересами отдельного индивидуума и общества, констатация проникновения отчуждения во все поры социальной жизни, акцент на психологиче- 
ских переживаниях личности, утверждение абсурдности бытия - все эти качества, характерные для экзистенциалистских мировоззренческих установок, свойственны и творчеству Сиина Риндзо, в первую очередь роману «Вечный пролог». Само название романа, содержащее семантически противоречащие друг другу слова, иллюстрирует противоречивость и контрастность всего творчества японского прозаика, наделённого ярким литературным дарованием, которое обернулось вечным прологом к подлинному искусству.

Роман Сиина автобиографичен. Его главный герой, альтер эго писателя по имени Сунагава Анта, напряжённо пытается разобраться в проблеме смысла человеческого существования и обрести своё подлинное $Я$. В первой части романа повествуется о детстве и юности Сунагава, выросшего в бедной семье, которую постоянно преследовал рок смерти: один за другим умирали его отец, мать, сёстры... Мысли о неумолимой и безжалостной смерти, требующей всё новых жертв, гнетут героя и он, не выдержав напряжения от страха стать следующим, сбегает из дому. Вся его дальнейшая жизнь превращается в вечное ожидание конца.

В годы Второй мировой войны Анта идёт служить в армию, где его жизнь находится под постоянной угрозой гибели, протекает в условиях столь любимой экзистенциалистами “пограничной ситуации”. Получив ранение, он попадает в госпиталь и тамошний врач, Такэути Гиндзиро, ампутирует ему ногу. Всё дальнейшее повествование составляют воспоминания героя о прожитой жизни и хроника его последних дней. Состояние молодого человека неуклонно ухудшается, к нему приходят мысли о самоубийстве. «В конце концов, - размышляет Анта, - не есть ли моя жизнь бессмыслица? Но несмотря на это я почему-то продолжаю существовать. Может, моя последняя и единственная свобода - самоубийство?» $[17$, с. 40]. Эта идея находит сочувствие у врача Такэути Гиндзиро, который сам снедаем страхом смерти и предлагает герою вместе выпить цианистого калия. «Все хотят умереть. Каждый способный решится на самоубийство, счастливец, выносит врач свой приговор. - Человечество - это сборище глупцов... Единственное спасение - это гибель» $[17$, с. 61-62]. В итоге Такэути всё же решается на суицид, устраивая пожар в собственном жилище и погибая в огне. В лице этого героя Сиина рисует трагическую эволюцию личности, пришедшей от малодушной философии отрицания ценности человеческого существования к непосредственному воплощению в жизнь такой философии, оборачивающейся элементарным уголовным преступлением. При этом символична профессия врача, данная автором Такэути. Суть врачебной деятельности - исцелять, спасать жизнь, дарить здоровье. «Врачевание» же этого экзистенциалистского персонажа наполнено прямо противоположным содержанием и отражает негативистское и драматическое мироощущение самого Сиина Риндзо.

В описании смерти Сунагава Анта в финале романа явственно звучат ноты светлой печали, отражающей чисто японское, традиционно безбоязненное, буддийски-бесстрастное в своей основе отношение к смерти [19, с. 271-274]. Герой достигает просветления, растворяясь в мире, обретая в смерти единение с ним. На наш взгляд, Сиина всё же в немалой степени склонен к обращению к духовным корням своего народа. Отметим, что тема смерти всегда выпукло присутствовала в литературе и культуре Японии. Вспомним блистательных дам и кавалеров эпохи Хэйан. Нет почти ни одной главы романа Мурасаки Сикибу «Гэндзи моногатари», где герои не упоминали бы о скорой (собственной или любимого) смерти. Жизнь аристократии в условиях постоянной памяти о скоротечности жизни и её конечности подпитывалась эстетизмом отношения к жизни, красота переживания которой делала и смерть эстетизированной, предметом поэтического и литературного творчества, элегических раздумий. Последовавший период междоусобных войн привёл к ещё большей эстетизации не только жизни, но и самой смерти. Ещё живым самурай должен был обдумать все возможные варианты ухода из жизни (от воды, от огня, от меча противника, от болезни и т.д.), чтобы при наступлении предсмертной ситуации не ударить в грязь лицом и принять все меры для красивого ухода из жизни: ритуал самоубийства-сэппуку был эстетизирован и разработан в подробностях. В мирную эпоху Токугава такой ритуал был усвоен и низшими сословиями. В пьесах популярного драматурга Тикамацу Мондзаэмона торговцы и гейши в безнадёжных для их любви и общественной морали ситуациях совершают обдуманные ритуализированные самоубийства. Известно, что и в Новейшее время Япония является одной из стран-лидеров по самоубийствам.

Мы уже фиксировали близость творчества Сиина идеям Достоевского, перед которым проблема самоубийства стояла очень остро. Христианство, которое русский писатель выстрадал пережив публичную казнь и каторгу, налагало строгий запрет на такое проявление свободы, как суицид, и идеологи волюнтаристского ухода из жизни в его романах почти всегда выступают отрицательными персонажами. Свидригайлов, Ставрогин, Смердяков - люди разного умственного и эмоционального склада, но все они аморальные, «преступившие черту». Христос - истина сверхприродная, Его Закон выше законов природы, неизменно и равнодушно унич- 
тожающей свои творения. Герои Достоевского и различаются на положительных и отрицательных именно тем, какую истину они выбирают - природную (война всех со всеми, победа сильного, главенство инстинкта, победа тлена над цветением, смерти над жизнью) или истину культурную (свобода следования за Христом, взвалив на себя свой крест и претерпев всё до конца).

Герои Сиина Риндзо - врач Гиндзиро Такэути и Сунагава Анта - перед лицом войны, обессмысливающего жизнь мирового страдания, выбирают разную смерть. Финальный жест Гиндзиро (поджог собственного жилища) чудовищен именно тем, что он подтверждает идею бессмысленности всего мироздания, заслуживающего адского пламени: Гиндзиро сам выносит и себе, и, образно выражаясь, «дому бытия» смертный приговор. Здесь нашли отражение погребальные настроения переживших ужасы войны японцев. Уход из жизни Анта - иной. Он донёс свой крест до конца, по сути, это смерть христианина, верящего в осмысленность и неслучайность всего происходящего с людьми на этом свете.

В противоречивом образе Сунагава Анта нашли отражение этические искания японского писателя, приведшие к утверждению в его мировоззренческих установках идей, сходных с идеями виднейшего представителя католического экзистенциализма, Габриэля Марселя (1889-1973), испытавшего влияние всей европейской мысли, и в частности, Ф. Шеллинга, С. Кьёркегора, А. Бергсона [13, с. 163]. Марсель рассматривает христианское мировоззрение как средство преодоления экзистенциального одиночества, а в его этике ощутимо определённое влияние практической философии И. Канта. Кант выдвинул не теоретическое, а нравственное обоснование бытия Божия, рассматривая Бога как необходимый постулат практического разума. Он доказывал, по существу, наличие Бога "от противного": не может быть так, чтобы всё кончалось несправедливостью; поскольку же моральный, справедливый человек в жизни, как правило, страдает больше аморального, то должен существовать такой мир, где осуществлялось бы торжество справедливости, и такая сила, которая бы обеспечивала это торжество, т.е. Бог, являющийся гарантом справедливости, регулятивным идеалом. По Канту, «нашим долгом было содействовать высшему благу, стало быть, мы имели не только право, но и связанную с долгом как потребностью необходимость предположить возможность этого высшего блага, которое, поскольку оно возможно только при условии бытия Божьего, неразрывно связывает предположение этого бытия с долгом, т.е. морально необходимо признавать бытие Божье» [5, с. 458].
Аморализм, воцаряющийся в условиях отсутствия Бога как регулятивного идеала, ведёт человечество к саморазрушению, вседозволенность приводит к трагическим последствиям. Поскольку этого быть не должно, постольку обязательно существование Бога как гаранта людской моральности. Сиина же в «Вечном прологе» ещё не приходит к идее обоснования моральности Божественным провидением. Он не разделяет взгляда авраамических религий на Бога как трансцендентного регулятора и источника моральной справедливости. Однако логика мысли японского писателя во многом повторяет логику Канта, он также прибегает к доказательству “от противного". Поскольку отсутствие моральных идеалов, бесчеловечность, пессимистический негативизм и деструктивные интенции его героя Такэути Гиндзиро приводят к преступлению и разрушению окружающей действительности, постольку необходимо наличие таких моральных идеалов, необходимо человеколюбие и открытое восприятие мира.

Авторская идея «Вечного пролога» эволюционирует от образа Гиндзиро как носителя неких тёмных сил к образу просветлённого в момент смерти Сунагава Анта, Анта выступает в романе как антиГиндзиро. Здесь Сиина утверждает моральность (истинность, справедливость) как нечто, являющееся противоположным аморальности (неистинности, несправедливости). Это некое отрицательное обоснование моральности. Положительного, позитивного обоснования её в рамках «Вечного пролога» ещё нет, что и роднит роман с сочинениями экзистенциалистов.

К идее необходимости поиска такого обоснования Сиина Риндзо придёт на следующем этапе своего творчества, когда в этико-философских исканиях начнёт постулировать идею Бога как позитивного обоснования моральности, как гаранта моральной справедливости. Этим же объясняется факт крещения японского писателя в 1951 г. Неслучайно он в том же году написал повесть «Красный отшельник» (Акаи кодокуся), где герой достигает просветления на пути единения с Иисусом Христом. «Сиина Риндзо как будто стремится к яркому свету, - справедливо отмечает японский критик и публицист Курахара Корэхито. - Однако он ищет света так, как летит на свет мушка, попавшая в темноту, он не видит света в самой действительности, он ищет света потому, что действительность отвратительна и бессмысленна, потому, что она нестерпима, а так как свет никак не вяжется с его представлением о действительности, то и оказывается совершенно искусственным» [7, с. 23].

Первым произведением, написанным после крещения Сиина Риндзо, стал роман «Неожиданная 
встреча» (Кайко, 1952). В нём писатель попытался совместить внутренние и внешние аспекты бытия «на основе синтеза христиански окрашенного экзистенциального реализма и социального реализма» $[17$, с. 500]. Образ главного персонажа романа, рабочего Фурусато Ясуси, является дальнейшим развитием образа просветлённого христианством героя «Красного отшельника». В 1955 г. Сиина печатает роман «Прекрасная дама» (Уиукусий онна), центральному персонажу которого даёт силы жить лелеемый им в сердце образ Божьей матери. Религиозные мотивы явственно звучат и в выпущенной в 1957 г. повести «Моё библейское повествование» (Ватакуси-но сэйсё-моногатари), являющейся исповедью новообращённого христианина.
На закате творчества, в романе «Длинное ущелье» (Нагай танима) и других произведениях, особенно, в своём последнем романе «Дело каторжника» (Тёэкинин-но кокухацу, 1969) писатель продолжает варьировать тему смерти. Пользуясь выражением самого Сиина, он считает жизнь вечным прологом к смерти. Однако все попытки Сиина Риндзо опереться на религиозно ориентированную субъективность, на духовную активность отдельного индивидуума, игнорирующего реальную социальную действительность, не увенчались успехом. Его писательская карьера, завершившаяся кризисом, продемонстрировала интеллектуальную и эмоциональную тупиковость пути, предлагаемого экзистенциализмом.

\section{Список литературы:}

1. Вацудзи Тэцуро. Дзэнсю (Полн. собр. соч.). Т. 8. Токио: Иванами сётэн, 1962. 563 с.

2. Григорьева Т.П. Японская литература ХХ века. М.: Художественная литература, 1983. 302 с.

3. Гэндай нихон бунгаку дзитэн (Словарь современной японской литературы). Токио: Токёдо сюппан, 1968.784 с.

4. Забережная О.А. Идеология литературного объединения «Сиракаба»: Автореф. ... кандидата культурологии. М., 2016. 28 c.

5. Кант И. Соч.: в 6 т. Т. 4, ч. 1. М.: Мысль, 1965. 544 с.

6. Козловский Ю.Б. Философия экзистенциализма в современной Японии. М.: Наука, 1975. 183 с.

7. Курахара К. Статьи о современной японской литературе. М.: Изд-во восточной литературы, 1959. 212 с.

8. Луцкий А.Л. К проблеме экзистенциализма в японской художественной литературе // Теоретические проблемы литератур Дальнего Востока. М.: Наука, 1986. С. 237-245.

9. Миякава Хидэки. Мэйдзи исин то нихон кэймосюги (реставрация Мэйдзи и движение просветительства в Японии). Токио: Иванами сётэн, 1971. 320 с.

10. Мори Ёити. Дзэн то сэйё сисо (Дзэн и европейская мысль). Токио: Иванами сётэн, 1968. 279 с.

11. Ниситани Кэйдзи. Нихиридзуму (Нигилизм). Токио: Со:бунся, 1989. 290 с.

12. Ниситани Кэйдзи. Сюкё ва нани ка (Религия - что это такое?). Токио: Тикума сёбо, 1961. 129 с.

13. Нихон бунгаку аннай. Киндай хэн (Справочник по японской литературе. Новейшее время). Токио: Асахи сюппанся, 1977. 472 c.

14. Нихон бунгаку дзэнси (Общая история японской литературы). Т. 6. Токио: Гакутося, 1979.

15. Рёхо К. Современный японский роман. М.: Художественная литература. 1977. 303 с.

16. Сайгуса Хирото. Нихон-ни окэру тэцугакутэки каннэнрон-но хаттэн (Распространение философского идеализма в Японии). Токио: Иванами сётэн, 1969. 389 с.

17. Сиина Риндзо сю (сочинения Сиина Риндзо) // Гэндай бунгаку тайкэй (Серия современной литературы). Т. 56. Токио: Бунгэй сюндзю, 1966. С. 211-486.

18. Синдо Дзюнко. Сакухин тэмпо сёва бунгаку (Обзор произведений литературы эпохи Сёва). Токио: Тайхэй инсацуся, 1977. 352 с.

19. Скворцова Е.Л., Луцкий А.Л. Духовная традиция и общественная мысль в Японии XX века. М.; СПб.: Центр гуманитарных инициатив; Университетская книга, 2014. 380 с.

20. Скворцова Е.Л. Луцкий А.Л. К проблеме восприятия западной философии в Японии // Вопросы философии. 1985. № 10. С. 132-139.

21. Судзуки Тору. Кёсонтэки сэкай (Мир - эхо бытия). Токио: Иванами сётэн, 1967. 328 с.

22. Танабэ Хадзимэ. Дзэнсю (Полн. собр. соч.). Т. 13. Токио: Иванами сётэн, 1964. 541 с.

23. Философия. Религия. Культура. М.: Наука, 1982. 401 с.

24. Философские вопросы буддизма. Новосибирск: Наука, 1984. 133 с.

25. Философский энциклопедический словарь. М.: Советская энциклопедия, 1983. 836 с.

26. Х Хайдеггер М. Время и бытие. М.: Республика, 1993. 446 с.

27. Швейцер А. Культура и этика. М.: Прогресс, 1973. 343 с.

28. Янагида Кэндзюро. Эволюция моего мировоззрения. М.: Политиздат, 1957. 162 с.

29. Izutsu Toshihico, Izutsu Toyo. The Theory of Beauty in the Classical Aesthetics of Japan. The Hague - Boston - London, 1981. $348 \mathrm{p}$.

30. Nishitani Keiji. The Meaning of Nihilism for Japan // Japanese Philosophy. A Sourcebook. Honolulu: Univ. of Hawai'i Press, 2011. P. 251-342.

31. Okakura Kakuzo. The Ideals of East. Alexandria. USA: Published by Library of Alexandria, 1994. 228 p.

\section{References (transliterated):}

1. Vatsudzi Tetsuro. Dzensyu (Poln. sobr. soch.). T. 8. Tokio: Ivanami seten, 1962. 563 s. 


\section{Филология: научные исследования 4(24) • 2016}

2. Grigor'eva T.P. Yaponskaya literatura XX veka. M.: Khudozhestvennaya literatura, 1983. $302 \mathrm{~s}$.

3. Gendai nikhon bungaku dziten (Slovar' sovremennoi yaponskoi literatury). Tokio: Tokedo syuppan, $1968.784 \mathrm{s.}$

4. Zaberezhnaya O.A. Ideologiya literaturnogo ob"edineniya «Sirakaba»: Avtoref. ... kandidata kul'turologii. M., $2016.28 \mathrm{s.}$

5. $\quad$ Kant I. Soch.: v 6 t. T. 4, ch. 1. M.: Mysl', 1965. 544 s.

6. Kozlovskii Yu.B. Filosofiya ekzistentsializma v sovremennoi Yaponii. M.: Nauka, 1975. 183 s.

7. Kurakhara K. Stat'i o sovremennoi yaponskoi literature. M.: Izd-vo vostochnoi literatury, 1959. $212 \mathrm{s.}$

8. Lutskii A.L. K probleme ekzistentsializma v yaponskoi khudozhestvennoi literature // Teoreticheskie problemy literatur Dal'nego Vostoka. M.: Nauka, 1986. S. 237-245.

9. Miyakava Khideki. Meidzi isin to nikhon keimosyugi (restavratsiya Meidzi i dvizhenie prosvetitel'stva v Yaponii). Tokio: Ivanami seten, $1971.320 \mathrm{~s}$.

10. Mori Eiti. Dzen to seie siso (Dzen i evropeiskaya mysl'). Tokio: Ivanami seten, 1968. 279 s.

11. Nisitani Keidzi. Nikhiridzumu (Nigilizm). Tokio: So:bunsya, 1989, 290 s.

12. Nisitani Keidzi. Syuke va nani ka (Religiya - chto eto takoe?). Tokio: Tikuma sebo, 1961. $129 \mathrm{~s}$.

13. Nikhon bungaku annai. Kindai khen (Spravochnik po yaponskoi literature. Noveishee vremya). Tokio: Asakhi syuppansya, 1977. $472 \mathrm{~s}$.

14. Nikhon bungaku dzensi (Obshchaya istoriya yaponskoi literatury). T. 6. Tokio: Gakutosya, 1979.

15. Rekho K. Sovremennyi yaponskii roman. M.: Khudozhestvennaya literature, 1977. $303 \mathrm{s.}$

16. Saigusa Khiroto. Nikhon-ni okeru tetsugakuteki kannenron-no khatten (Rasprostranenie filosofskogo idealizma v Yaponii). Tokio: Ivanami seten, 1969. $389 \mathrm{~s}$.

17. Siina Rindzo syu (sochineniya Siina Rindzo) // Gendai bungaku taikei (Seriya sovremennoi literatury). T. 56. Tokio: Bungei syundzyu, 1966. S. 211-486.

18. Sindo Dzyunko. Sakukhin tempo seva bungaku (Obzor proizvedenii literatury epokhi Seva). Tokio: Taikhei insatsusya, 1977. $352 \mathrm{~s}$.

19. Skvortsova E.L., Lutskii A.L. Dukhovnaya traditsiya i obshchestvennaya mysl' v Yaponii XX veka. M.; SPb.: Tsentr gumanitarnykh initsiativ; Universitetskaya kniga, 2014. $380 \mathrm{~s}$.

20. Skvortsova E.L. Lutskii A.L. K probleme vospriyatiya zapadnoi filosofii v Yaponii // Voprosy filosofii. 1985. № 10. S. 132139.

21. Sudzuki Toru. Kesonteki sekai (Mir - ekho bytiya). Tokio: Ivanami seten, 1967. $328 \mathrm{~s}$.

22. Tanabe Khadzime. Dzensyu (Poln. sobr. soch.). T. 13. Tokio: Ivanami seten, 1964. $541 \mathrm{~s}$.

23. Filosofiya. Religiya. Kul'tura. M.: Nauka, 1982. $401 \mathrm{~s}$.

24. Filosofskie voprosy buddizma. Novosibirsk: Nauka, 1984. $133 \mathrm{~s}$.

25. Filosofskii entsiklopedicheskii slovar'. M.: Sovetskaya entsiklopediya, 1983. $836 \mathrm{s.}$

26. Khaidegger M. Vremya i bytie. M.: Respublika, 1993. $446 \mathrm{s.}$

27. Shveitser A. Kul'tura i etika. M.: Progress, 1973. 343 s.

28. Yanagida Kendzyuro. Evolyutsiya moego mirovozzreniya. M.: Politizdat, 1957. $162 \mathrm{s.}$

29. Izutsu Toshihico, Izutsu Toyo. The Theory of Beauty in the Classical Aesthetics of Japan. The Hague - Boston - London, 1981. $348 \mathrm{p}$.

30. Nishitani Keiji. The Meaning of Nihilism for Japan // Japanese Philosophy. A Sourcebook. Honolulu: Univ. of Hawai'i Press, 2011. P. 251-342.

31. Okakura Kakuzo. The Ideals of East. Alexandria. USA: Published by Library of Alexandria, 1994. 228 p. 